\title{
SPACE POWER REACTOR GROUND TEST IN THE EXPERIMENTAL GAS COOLED REACTOR (EGCR) AT OAK RIDGE*
}

\author{
M. H. Fontana \\ R. S. Holcomb \\ R. H. Cooper
}

Oak Ridge National Laboratory

Oak Ridge, Tennessee 37831-8063

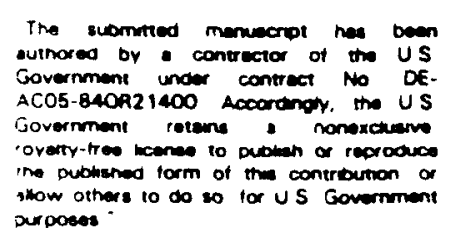

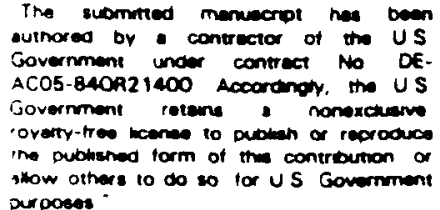
purooses

\begin{abstract}
The Experimental Gas Cooled Reactor (EGCR) facility and the supporting technical infrastructure at the Oak Ridge National Laboratory have the capabilities of performing ground tests of space nuclear power reactor systems. A candidate test would be a $10 \mathrm{MWt}$ lithium cooled reactor, generating potassium vapor that would drive a power turbine. The facility is a large containment vessel originally intended to test the EGCR. Large, contained, and shielded spaces are available for testing, assembly, disassembly, and post-test examination.
\end{abstract}

Scope. The EGCR facility at the Oak Ridge National Laboratory (ORNL), along with the existing supporting technical infrastructure, has the capability for performing ground tests of a space nuclear power reactor. It is most likely that the concept of choice will be a Rankine cycle system using a lithium-cooled reactor transferring heat to a potassium boiler and potassium vapor power conversion cycle. A space radiator for heat dump could be tested, but it would be desirable to dump heat through a conventional heat exchanger and perform the space radiator tests separately.

Background. ORNL has a broad and diversified background in nuclear reactor development and testing which has involved all phases of reactor technology. Among the many reactor projects which ORNL has conducted. three are particularly pertinent - the Space Nuclear Auxiliary Power (SNAP) Medium Power Reactor Experiment (MPRE), a $150 \mathrm{~kW}$ (e) system; the Army Portable Power Plant, a $2500 \mathrm{~kW}$ (e) system; and the Missile Base Power Plant, a $1000 \mathrm{~kW}$ (e) system. For the MPRE Program. ORNL envisioned a lightweight, low-temperature, state-of-the-art space auxiliary power system using a compact reactor cooled by boiling potassium, lightweight shadow shielding, a simple direct Rankine cycle with potassium condensation in a cylindrical radiator equipped with tapered tubes. fins. and reflectors. A series of test systems incorporating representative components such as the potassium vapor driven boiler feed pump were successfully operated during the program.

Additionally, ORNL has also been deeply involved in the overall Gas Cooled Reactor Program and the Liquici Metal Fast Breeder Reactor Program for many years.

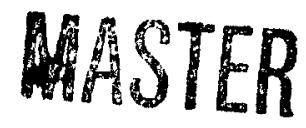

- Based on work performed at Oak Ridge National Laboratory, managed for the U.S. Department of Energy under contract DE-AC05-84OR21400 with Martin Marietta Energy Systems, Inc. 


\section{DISCLAIMER}

This report was prepared as an account of work sponsored by an agency of the United States Government. Neither the United States Government nor any agency Thereof, nor any of their employees, makes any warranty, express or implied, or assumes any legal liability or responsibility for the accuracy, completeness, or usefulness of any information, apparatus, product, or process disclosed, or represents that its use would not infringe privately owned rights. Reference herein to any specific commercial product, process, or service by trade name, trademark, manufacturer, or otherwise does not necessarily constitute or imply its endorsement, recommendation, or favoring by the United States Government or any agency thereof. The views and opinions of authors expressed herein do not necessarily state or reflect those of the United States Government or any agency thereof. 


\section{DISCLAIMER}

Portions of this document may be illegible in electronic image products. Images are produced from the best available original document. 
ORNL has had, and is continuing, a deep involvement in liquid metals technology, including high-temperature materials development, component and systems development, and instrument design and testing. Extensive resources are available in shielding analysis and testing, neutronics, systems analysis and evaluation, fuels and structural materiais development and testing, and safety analysis for all types of reactor systems. Remote maintenance and repair of radioactive systems was important to the Homogeneous and Molten Salt Reactor concepts and experience gained there continues to be developed as part of the Robotics Program. ORNL is fully competent to undertake a major role in space power reactor development.

The ORNL professional staff is both varied and substantial: it includes 660 chemical, electrical, mechanical, and nuclear engineers; 670 physical scientists; 330 biomedical and environmental scientists; and 40 economists, geographers, and other social scientists.

A strong program management capability exists in the Martin Marietta Energy Systems complex at Oak Ridge, as evidenced by the success of major projects such as: Gaseous Diffusion Plant Cascade Improvement Program; Gaseous Diffusion Plant Cascade Upgrading Program; Gaseous Diffusion Plant Gas Centrifuge Program; Holifield Heavy Ion Research Facility; ISX Tokamak Facility; and Large Superconducting Coil Test Facility.

Resources available for the support of such projects include expertise in reactor operations, maintenance of radioactive systems, radiation monitoring, chemical analysis, environmental affairs, energy storage, quality assurance, and safety, with major support from the Engineering Division (1200 employees) and the Computer Sciences Division (500 employees), as well as the Purchasing Division and other necessary support functions.

The EGCR Facility.

The EGCR is located 2 miles east of the ORNL site on the bank of Melton Hill Lake, a navigable waterway. The facility is partially occupied by the ORNL Fuel Recycle Division, but the proposed areas for reactor testing are in standby condition. It is planned that, based on the type and size of reactor test proposed, either the experimenter's cells surrounding the containment vessel at grade or the charge machine room within the containment vessel and $\sim 50 \mathrm{ft}$ below grade (or some combination of both) will be used. These are shown in Figs. 1. and 2.

Experimenter's Cells. Experimental loop equipment cells are arranged in a horseshoe-shaped concrete room $24 \mathrm{ft}$ wide by $15 \mathrm{ft} 3 \mathrm{in}$. deep and $291 \mathrm{ft}$ in length external to the reactor building. This structure is subdivided by seven steel bulkheads into eight compartments of equal size. The cells are adjacent to the reactor containment building on the inner edge of the horseshoe; a 12-ft wide access tunnel is located on the outer edge of the horseshoe which could contain both temporary shielding, auxiliary equipment, and instrumentation. Each cell is equipped with two blanked-off penetrations which pass through the containment building wall. Equipment may be placed in the cells through an 11-ft 6-in. by 26-ft opening in each cell roof. A removable roof hatch covers each opening. Personnel access into each cell is through a roof penetration having a sealed door at the cell ceiling. A portable air lock will be connected to the top of the cell roof penetration for personnel entry. Cell shielding provided consists of 2 -ft-thick concrete walls, a 2 -ft 3 -in. thick roof slab. and a 1-ft 6-3/4-in. thick hollow steel bulkhead between cells. These cells are totally unoccupied.

Charge Machine Room. The charge machine room is the preferred location for a space reactor test. It is located in the lower volume of the EGCR containment building and is $\sim 50 \mathrm{ft}$ by $35 \mathrm{ft}$ by $42 \mathrm{ft}$ deep, and can provide reactor containment for an essentially unoccupied floor area of approximately $1800 \mathrm{ft}^{2}$ with $42 \mathrm{ft}$ of head room. The charge machine currently still in place could be removed with relative ease through the existing $10 \mathrm{ft}$ by $30 \mathrm{ft}$ ceiling hatch. If this volume were 
utilized for a large reactor test, the experimenters cells and other unoccupied space in the vicinity could be used for miscellaneous equipment, instrumentation, and controls.

Containment Building. The containment building is a 114-ft-diam cylindrical vessel with a hemispherical top head and a torospherical bottom head. The inside height is approximately $216 \mathrm{ft}$. The bottom head, - $70 \mathrm{ft}$ below grade, is encased in concrete. The cylindrical portion contains nozzles and penetrations required for ventilation, interconnection of systems, and two air locks, one for equipment or personnel and one for personnel only.

The containment building was designed to the ASME code for an internal pressure of 9 psig at $200^{\circ} \mathrm{F}$. The shell and head plates were constructed of SA-201, Grade B steel to A-300 requirements. All pressure stressed weld, welds attaching penetrations to the shell, and welds which, if defective, would represent a weakness in the structure were $100 \%$ radiographed except that magnetic particle or fluid penetrant inspections were used in the case of welds not amenable to radiography. The entire structure was pressure tested to 11.25 psig with air locks in place, and was leak tested at 9 psig after completion of all penetration.

The design of the containment building is in conformance with the ASME Boiler and Pressure Vessel Code sections: Section II, "Material Specifications;" Section VIII, "Unfired Pressure Vessels;" and Section IX, "Welding Qualifications."

In addition the ASME Nuclear Code Cases applied: 1270N, "General Requirements for Nuclear Vessels;" 1271N, "Safety Devices;" and 1272N, "Containment and Intermediate Containment Vessels."

The following tabulation lists the loads, pressure, and temperature used in the design.

Snow load

Insulation

Basic wind pressure, top head

Basic wind pressure, cylinder

Seismic, horizontal coefficient

Seismic, vertical coefficient

Internal pressure (design)

Max. temperature of contained gases

Min. factor of safety for buckling

Equipment air lock:

Moving load on 4 sets of wheels on

an area $5 \mathrm{ft}$ by $10 \mathrm{ft}$

Personnel air lock:

Floor live load

Equipment and personnel air locks:

External pressure

Internal pressure

External pressure (inside building)
$10 \mathrm{psf}$
$1 \mathrm{psf}$
$40 \mathrm{psf}$
$30 \mathrm{psf}$
$0.05 \mathrm{~g}$
$0.025 \mathrm{~g}$
$9 \mathrm{psig}$
$200^{\circ} \mathrm{F}$
4

$120,000 \mathrm{lbs}$

200 psf

2 psig

9 psig

9 psig

The thickness of the bottom head inciudes a 1/16-in. corrosion allowance. 
As indicated earlier, the charge machine room is an essentially unoccupied space and currently has no pertinent instrumentation and controls or vibration, environmental monitoring, or heat rejection capability. Two $40 \mathrm{MW}(\mathrm{t})$ steam generators and an essentially inexhaustible supply of miscellaneous hardware, service, and utility equipment still reside in the containment building.

Support Systems. $\quad$ Systems assembly would be done in ORNL, Y-12, and/or Oak Ridge shops and in available and appropriate space in or near the particular test facility being used. System disassembly would be done as appropriate in-situ, in available space in or near the test facility, and/or in the extensive hot cell facilities within the ORNL complex. Post-test examination would take place in the metallurgical and analytical hot cells at ORNL - the High Radiation Level Examination Laboratory (HRLEL), the Segmenting Cells (Bldg. 3026D), the Physical Examination Hot Cells (Bldg. 3025), and the High Radiation Level Analytical Laboratory (HRLAL).

Electrical power is of primary importance to Oak Ridge area operations, and large quantities of power are available. Numerous high-voltage transmission lines from the Tennessee Valley Authority (TVA) power system enter or cross the Oak Ridge Reservation to supply this power. A 22-in.-OD natural gas line serves ORNL. This run could be tapped to supply natural gas to the EGCR site.

Reactor Ground Test Configuration. Figure 3 shows how a potassium vapor rankine cycle space power reactor could be configured for testing in the charge machine room of the EGCR. Figure 3 is a cross-section of the charge machine room, directly under the hatch. The assumed reactor configuration is a $50 \mathrm{MW}$ Thermal lithium cooled reactor which generates potassium vapor in a lithium to potassium vapor generator. The vapor passes through a turbine and then to a condenser which, for the purposes of the test, is a $\mathrm{NaK}$ heat exchanger. The $\mathrm{NaK}$ then dumps heat to a $\mathrm{NaK}$ to air heat exchanger. It is assumed that a space radiator would be tested separately from the reactor test, which is the subject of this paper.

The reactor would be fabricated of refractory metals, which must be operated in a vacuum. Therefore, a significant item would be the vacuum chamber, $9 \mathrm{ft}$ diameter by $30 \mathrm{ft}$ high, and associated equipment, shown in Figure 3. Also, liquid metal charging systems, contained in a inert atmosphere, would be included. The NaK heat dump system is designed so that a $\mathrm{NaK}$ to air heat exchanger could be isolatable to prevent dispersion of alkali metal oxides and hydroxides to the environment in the event of a leak and a fire. Instrumentation and control cabling would be routed to a control room either behind the existing shielding wall inside containment or to a room outside containment, possibly in the experimenters cells.

The reactor would be assembled off site and brought into the test area through the equipment airlock and hatch. Disassembly could be performed remotely and samples moved to the hot cell and post test examination facilities in the Oak Ridge complex. Since the extensive Oak Ridge Robotics Division activities are presently at the EGCR site, little problem is expected in the event that robotics techniques are used for repair and disassembly.

Additional Equipment Needed. Additional capital equipment would include a vacuum chamber; possibly a crane over the experimenters' cells if those are used; a new data acquisition system and control room: a remote handling system for decontamination and removal of experimental equipment after test completion; stainless steel liner tor the charge machine room, if that is used (that is the preferred site); and liquid metal handling facilities, such as tanks, cover gas control, and fire prevention and control. 


\section{EXPERIMENTAL GAS COOLED REACTOR BUILDING VERTICAL SECTION}

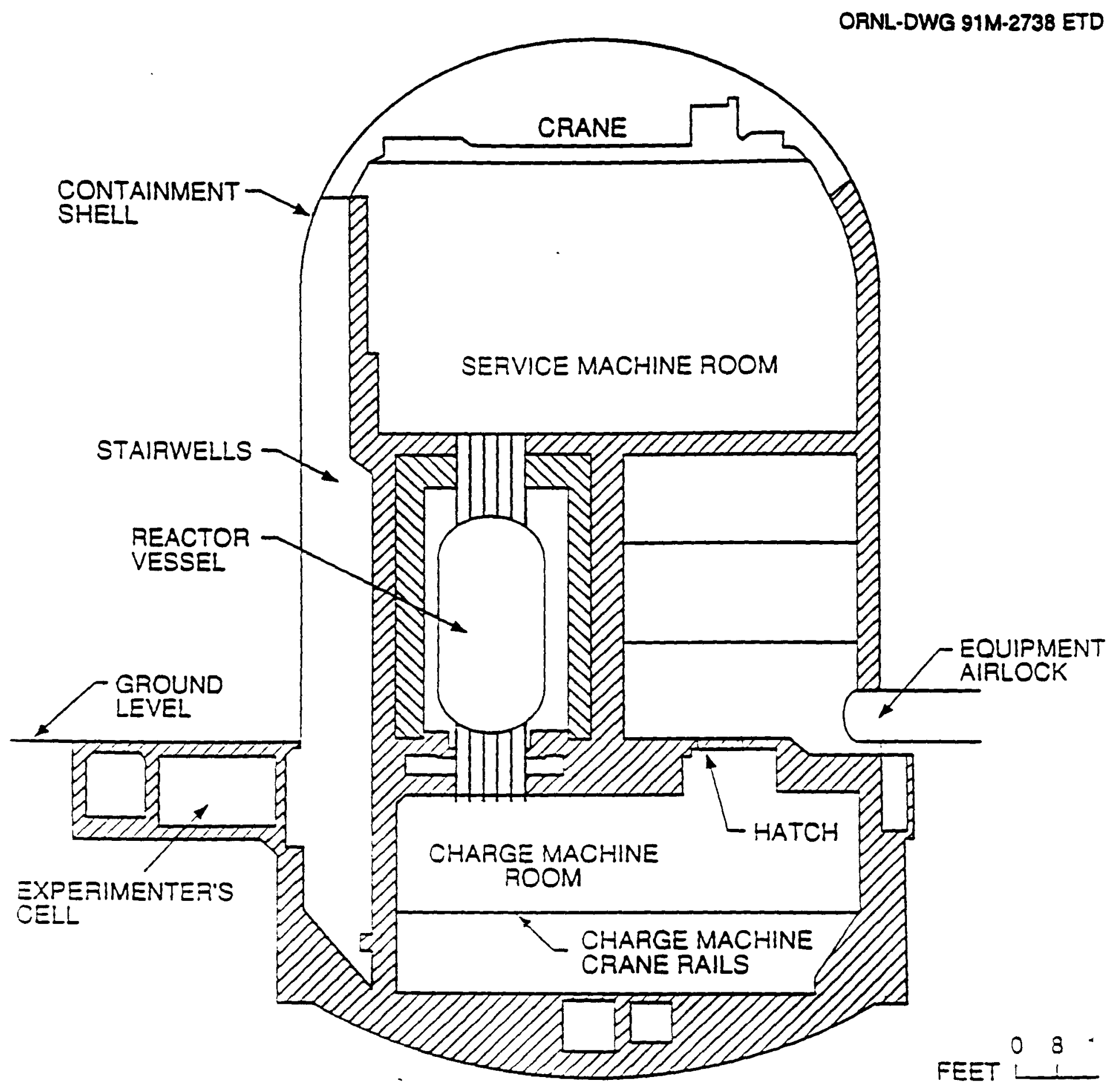

Fig. 1 
OANL-DWO 81,2730 ETD

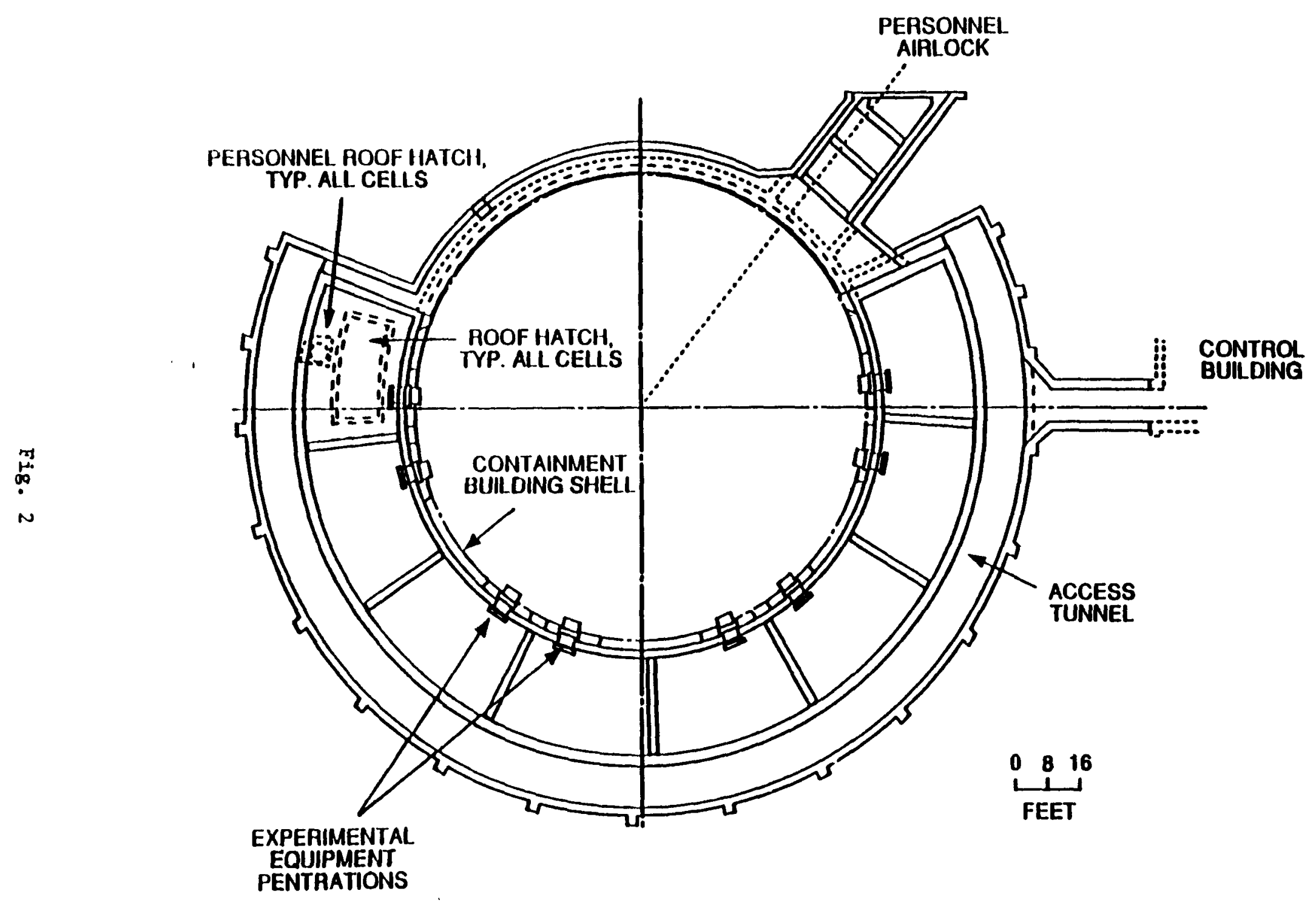

EXPERIMENTAL CELLS FLOOR PLAN 


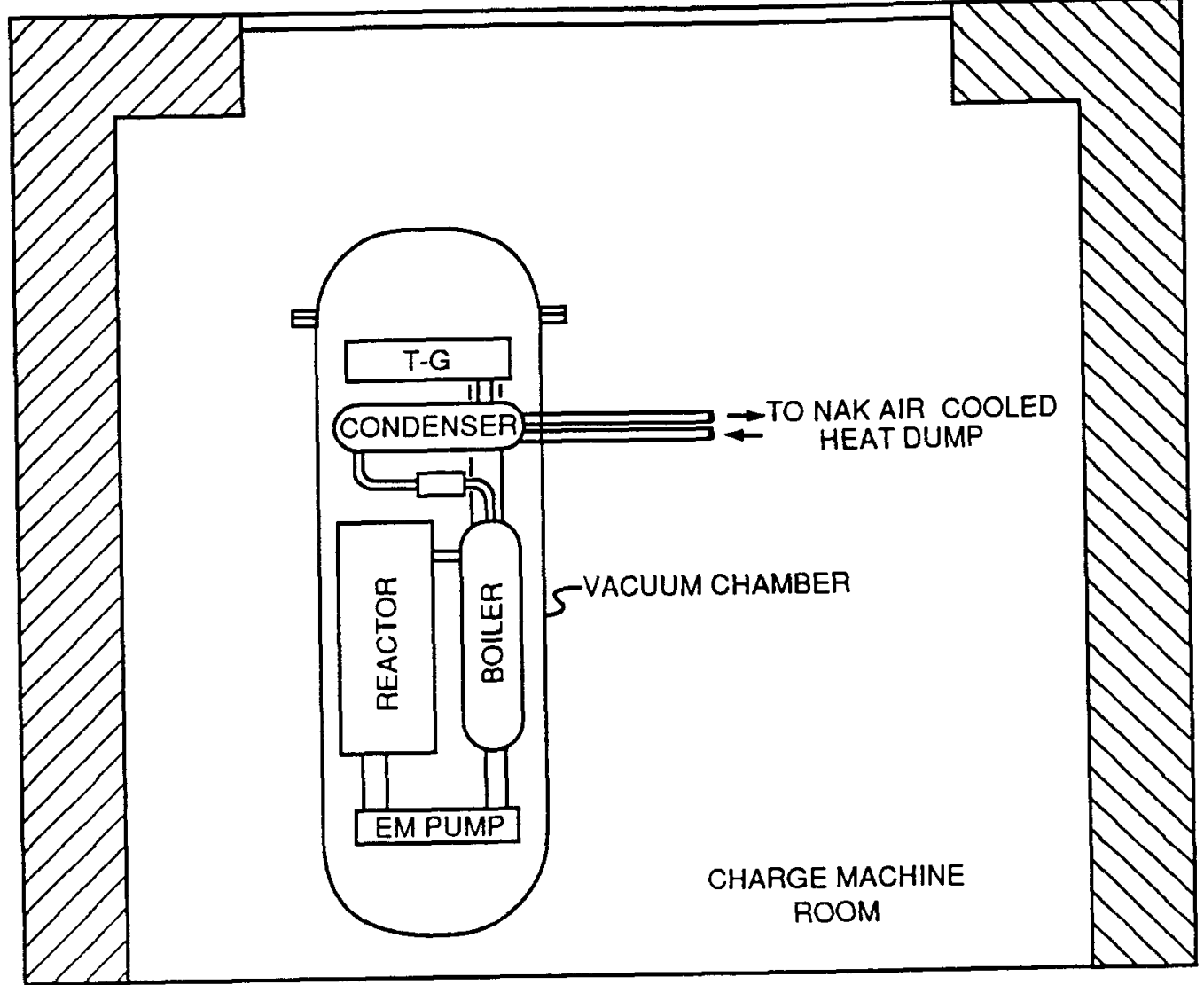

Fig. 3. Reactor ground test configuration

\section{DISCLAIMER}

This report was prepared as an account of work sponsored by an agency of the United States Government. Neither the United States Government nor any agency thereof, nor any of their employees, makes any warranty, express or implied, or assumes any legal liability or responsibility for the accuracy, completeness, or usefulness of any information, apparatus, product, or process disclosed, or represents that its use would not infringe privately owned rights. Reference herein to any specific commercial product, process, or service by trade name, trademark, manufacturer, or otherwise does not necessarily constitute or imply its endorsement, recommendation, or favoring by the United States Government or any agency thereof. The views and opinions of authors expressed herein do not necessarily state or reflect those of the United States Government or any agency thereof. 